\title{
Implementation of Corporate Social Responsibility in PT. Riau Andalan Pulp and Paper in Pelalawan District, Riau Province
}

\author{
Made Devi Wedayanti ${ }^{1}$, Achmad Nurmandi ${ }^{2}$, Hasse Jubba ${ }^{3}$, Septa Juliana ${ }^{4}$ \\ Universitas Islam Riau, Pekanbaru, Indonesia ${ }^{1,4}$, Doctoral Program of Islamic Politics - Political Scince, \\ Universitas Muhammadiyah Yogyakarta- Indonesia ${ }^{2}$, Department of Islamic Politics Political Science, \\ Universitas Muhammadiyah Yogyakarta ${ }^{3}$ \\ madedeviwedayanti@soc.uir.ac.id ${ }^{1}$, nurmandiachmad@umy.ac.id²,hasse@umy.ac.id² , \\ septajuliana@soc.uir.ac.id ${ }^{4}$
}

\begin{abstract}
This study aims to see and measure the successful implementation of CSR programs in PT. RAPP through 4 indicators out of 8 indicators used in measuring the key performance of CSR implementation according to Ernie 2009 and looking for solutions to problems concerning environmental preservation around PT. RAPP. The stages of the research method used are qualitative methods through a case study approach with the stages of understanding the case studies to be examined, conducting prariset observations, collecting both primary and secondary data related to research, analyzing data, determining informants, conducting interviews, research observations, document research and conclude the research results obtained. The results of the 4 indicators used are first, leadership is in the "good" category. Second, the proportion is in the "good" category. Third, transparency \& accountability are in the "good" category. Fourth, the regional scope, is in the category of "good enough".
\end{abstract}

Keywords: Implementation, Policy, Corporate Social Responsibility, Development

\section{Introduction}

The implementation of Corporate Social Responsibility shows that the company is not only a business activity, but the company is an agency that must also think about the economic, social and environmental conditions needed around the company. On the other hand companies and communities have close social interaction. The sustainability of the company's business is very dependent on the quality of people's lives and the economy of the community. In its operations the company must not only think about profits but must participate in paying attention to environmental sustainability and care for the social problems of the community around the company. One of the efforts of the regional government of Riau Province in regulating the implementation of CSR is to make regional regulations of Riau Province No 6 of 2012 concerning corporate social responsibility in Riau Province. However hing g a currently defined rules have not been able to prevent the environmental damage caused by waste companies one example is PT.RAPP that caused thousands of dead fish in the river Kampar and the emergence of stinging stench nose that interferes with the activity and health of the surrounding community.

On the other hand, PT. RAPP has been awarded the CSR Program as a company that runs CSR programs in a constructive and consistent manner by the Regent of Pelalawan and PT. RAPP also received a 2013 Green Industry award from the government. 
According to Law Number 40 Year 2007, a Limited Liability Company (company) is a legal entity which is a capital alliance, established based on an agreement, carries out business activities with authorized capital which is entirely divided into shares, and meets the requirements stipulated by the laws and implementing regulations. . Furthermore Riau Province has Regulation No. 6 of 2012 concerning corporate social responsibility. Companies and communities have social interactions. The company has indirectly affected all lines of people's lives. The sustainability of the company's business is very dependent on the quality of people's lives and the economy of the community. In its operations the company must not only think about profits but must participate in paying attention to environmental sustainability and care for the social problems of the community around the company.

Based on data from the Riau Province Statistics Agency in 2017, Riau Province has 219 Large and Medium Industrial Companies and one of the large companies in Riau province is PT. Riau Andalan Pulp and Paper in Pelalawan Regency or better known as PT. RAPP. PT.RAPP is one of the largest pulp and paper producers, with the latest and most efficient technology in the world. Making products used by millions of people every day in the form of liquid objects, paper for printing and writing, tissue, shopping bags, food packaging, magazines and books.

Based on data obtained from PT. RAPP that PT. RAPP disbursed approximately US \$ 4.6 million in funds for a year for corporate social activities ( CSR). The social programs undertaken by the company include an integrated farming system of USD 500 thousand, education of USD 400 thousand, social infrastructure of USD 1.1 million, and other community empowerment programs of USD 2.6 million. In addition PT.RAPP have earned the Award on CSR program her as the company running the CSR program constructively and consistently by Pelalawan District and PT. RAPP also received a 2013 Green Industry award from the government.

Policy implementation is a legal administration tool where various factors, organizations, procedures and techniques work together to carry out policies in order to achieve the desired impact or objectives. The specific purpose of this research is to see and measure the successful implementation of CSR programs in PT. RAPP through 8 indicators used in measuring the key performance of CSR implementation according to Ernie 2009 and find solutions to problems related to environmental preservation around PT. RAPP.

This research is very important to be investigated because with the existence of CSR programs in Pelalawan district, there is an increase in the regional economy regarding employment opportunities for local people, community empowerment, scholarships and other positive programs that need attention, but on the other hand the phenomenon that has recently occurred in Pelalawan Regency is very endanger public health, especially for children and toddlers who are around the company.

\section{Literature Review}

Various references of the authors make it as a reference to see the extent of the research carried out by previous researchers and to see the renewal and the state of the art of this research. The references that the authors collect are through national and international journals. The concept of CSR is known as legal responsibility in the form of obligations for companies to improve the welfare of the people who live around the company's location [1]. Likewise [2] CSR is a long-term corporate activity for the community through programs or 
special expertise in independently increasing economic prosperity. Furthermore [1] explains that CSR is the company's responsibility to the community which if not implemented will be subjected to administrative sanctions in the form of written warnings, restrictions on business activities, freezing of business activities, up to the revocation of business activities by the government. From these various opinions, the conclusion of CSR researchers is a compulsory company activity for the community that is sustainable, responsible, transparent and has sanctions for companies that do not carry out these activities in support of increasing community empowerment and development.

Implementation of the CSR concept in practice still needs the support of indicators to make the implementation run optimally, such as support for the geographical conditions of the region, potential human resources owned and the collaboration between the Forum and the Village in the planning of a development and supervision [3]. This concept is supported by the standard implementation of CSR activities and good coordination between companies and government programs and the involvement of the community in its implementation is an important concern to achieve maximum CSR implementation [4]. In implementing CSR, it needs support from internal and external factors. Internal factors are the quality of human resources, while the external factors are the quality of the community to be responsible and take advantage of the programs provided [5].

Different from the opinion [5] in this matter [6], said that the CSR concept will run optimally if it starts with Social Mapping to determine the right CSR program, then the company cooperates with partners whose task is to provide education and guidance to community groups, and Evaluate funds in a transparent manner, and the results of activities need to be evaluated in the form of Annual Report.

So, from the various opinions it can be concluded that the concept of CSR can be seen by the multi- stakeholder collaboration of the government, companies and the community by taking into account geographical conditions, improving the quality of human resources both internally and externally of the company, the standard implementation of CSR and Social Mapping activities as the determination of the Program is appropriate, there is good coordination between the company and government programs, as well as the active involvement of the community, and then there is cooperation between the company and partners in the implementation of CSR activities.

There are 8 indicators that should be used in measurements for key performance in implementing CSR, namely [7]:

1) Leadeship (Leadership)

a) CSR programs can be said to be successful if they get support from top company management.

b) There is philanthropic awareness from the leadership which is the basis for implementing the program.

2) Proportion of Assistance

CSR is designed not solely on the budget range, but also at the level of maximum absorption, meaning that if the area is broad, then the budget must also be greater. So it cannot be used as a benchmark, if a large budget certainly produces a good program.

3) Transparency and Accountability

a) There is an annual report.

b) Having a social and financial audit mechanism where social audit is related to testing the extent to which CSR programs can be addressed properly according to the needs of the community, companies get feedback from the community correctly by conducting interviews with beneficiaries. 
4) Area Coverage

There is an orderly and rational identification of beneficiaries based on predetermined priorities.

5) Planning and Monitoring and Evaluation Mechanism

a) In planning there needs to be guarantees to involve multi-stakeholders in each project implementation cycle.

b) There is awareness to pay attention to aspects of locality (local wisdom), when planning there is a contribution, understanding, and acceptance of existing local cultures.

c) There is a blue-print policy which is the basis for implementing the program.

6) Stakeholder Engagement

a) There is a regular coordination mechanism with stakeholders, especially the community.

b) There is a mechanism that guarantees community participation to be involved in the project cycle.

7) Continuity

a) There was a transfer of role from the corporation to the community.

b) The growth of sense of belonging (sense of belonging) of the program and the results of the program in the community, so that the community can take part in maintaining and maintaining the program well.

c) There is a choice of program partners who can guarantee that without the participation of the company, the program can continue until it is finished with the partner.

8) Real results

a) There is documentation of results that indicate a reduction in morbidity and mortality (in the health sector), or a reduction in illiteracy rates and an increase in the ability of HR (in education) or other parameters in accordance with the chosen CSR field by the company.

b) The change in mindset of the people.

c) Providing a dynamic community economic impact.

d) Community empowerment occurred.

\section{Research Method}

The method used in this research is to use qualitative methods with the type of case study research, namely conducting research as a form of follow-up of events or cases that have occurred with the aim of wanting to find solutions to these problems . The data processing used is the result of interviews and is combined from several sources; books, journals and documents of the company's final annual report.

\section{Result and Discussion}

There are 8 indicators used in the measurement for key performance in implementing CSR, namely [7]:

1) Leadeship (Leadership)

a. CSR programs can be said to be successful if they get support from top company management. 
b. There is philanthropic awareness from the leadership which is the basis for implementing the program.

2) Proportion of Assistance

CSR is designed not solely on the budget range, but also at the level of maximum absorption, meaning that if the area is broad, then the budget must also be greater. So it cannot be used as a benchmark, if a large budget certainly produces a good program.

3) Transparency and Accountability

a. There is an annual report.

b. Having a social and financial audit mechanism where social audit is related to testing the extent to which CSR programs can be addressed properly according to the needs of the community, companies get feedback from the community correctly by conducting interviews with beneficiaries.

4) Area Coverage

There is an orderly and rational identification of beneficiaries based on predetermined priorities.

5) Planning and monitoring and evaluation mechanism

a. In planning there needs to be guarantees to involve multi-stakeholders in each project implementation cycle.

b. There is awareness to pay attention to aspects of locality (local wisdom), when planning there is a contribution, understanding, and acceptance of existing local cultures.

c. There is a blue-print policy which is the basis for implementing the program.

6) Stakeholder Engagement

a. There is a regular coordination mechanism with stakeholders, especially the community.

b. There is a mechanism that guarantees community participation to be involved in the project cycle.

7) Continuity

a. There was a transfer of role from the corporation to the community.

b. The growth of sense of belonging (sense of belonging) of the program and the results of the program in the community, so that the community can take part in maintaining and maintaining the program well.

c. There is a choice of program partners who can guarantee that without the participation of the company, the programcan continue until it is finished with the partner.

8) Real results

a. There is documentation of results that indicate a reduction in morbidity and mortality (in the health sector), or a reduction in illiteracy rates and an increase in the ability of HR (in education) or other parameters in accordance with the chosen CSR field by the company.

b. The change in mindset of the people.

c. Providing a dynamic community economic impact.

d. Community empowerment occurred .

Of the eight indicators of measurement for key performance in implementing CSR above, the authors limit the discussion in this study to only assessing four indicators namely first, leadership. Second, the proportion of assistance. Third, Transparency and Accountability. Fourth, Regional Coverage. 


\subsection{Leadership}

Asia Pacific Resources International Holdings Ltd. (APRIL) is a member of the RGE Group which was founded by Sukanto Tanoto in 1973. Under his leadership, the RGE Group has grown into a global business group that employs more than 60,000 employees, with total assets of more than US $\$ 18$ billion and worldwide sales reach.

As one of the pioneers of responsible companies, the APRIL Group and its subsidiaries implement the $5 \mathrm{C}$ principle which is trusted by Mr. Sukanto Tanoto. Business practices must bring good for the Community (Community), Country (Country), Climate (Climate), Customers (Customers) and ultimately good for the Company (Company). As such, corporate social responsibility is applied in the operations and management of the APRIL Group to advance the environment and develop the community and to fulfill corporate social responsibility. The Tanoto Foundation which was founded in 1981 is the application of this vision.

Through its Indonesian subsidiary, the APRIL Group began developing plantations in Riau Province, Sumatra and built a factory in Pelalawan Kerinci from 1993. At that time, Kerinci was home to only 200 households. This population grew to more than 200,000 in 2010 as the APRIL Group's business development and diversification turned Kerinci into a regional social and commercial center in the province. The APRIL Group began commercial pulp production in 1995, followed by commercial paper production in 1998. The growth of this region reflects the operational growth of the APRIL Group in Indonesia, with the formation of the Pelalawan District in 1999 and then the Kerinci municipality in 2001. Rapid Kerinci growth this then allowed it to be divided into three regions in 2005 .

In 2010, APRIL Group's forestry operational activities contributed 6.9 percent to the total economy of Riau Province. APRIL Group has created around 90,000 jobs for the community. APRIL also contributes to providing better access to education and social support in areas such as health care and housing. The APRIL group has helped improve living standards and reduce poverty levels by 30 percent. Based on the results of interviews and observations of the author of PT. RAPP forms the CD Section by dividing three CD heads, namely the Education, Employment and Enhancements CD sections. And these 3 sections will later carry out CSR programs in accordance with their respective sections that are created to create work programs and budgets needed for the implementation of CSR at the end of the year. The conclusion of the leadership indicators is in the "Good" category.

\subsection{Proportion of Assistance}

As a company that has more than 60,000 employees and as one of the pioneers of responsible companies, the APRIL Group and its subsidiary PT. RAPP always implements the 5C principle which is trusted by Mr. Sukanto Tanoto. Business practices must bring good for the Community (Community), Country (Country), Climate (Climate), Customers (Customers) and ultimately good for the Company (Company). Thus, corporate social responsibility is applied in many programs in the form of community development. such as building partnerships with the community as a form of corporate social responsibility. This partnership is demonstrated by empowering and encouraging the independence of the local community.

For nearly two decades, the APRIL Group (PT. RAPP) has contributed to community development in Riau Province by helping to reduce poverty and improve quality of life through various economic, health, education, and infrastructure development programs. Based on the results of interviews and observations, RAPP companies believe that 
education, health and infrastructure are the main keys in eliminating community poverty. Therefore this company is committed to contribute to society in these three factors through CSR.

\subsection{Education}

Education is important in improving human resources in an area so that the RAPP company provides scholarship programs from elementary to tertiary level, training of school teachers and providing school equipment. So far PT RAPP has been a). gave 17,613 scholarships to elementary and middle school students; b). Offering 50 scholarships for local high school graduates to continue their undergraduate agriculture studies at INSTIPER; c). Assisting the renovation and development of 219 schools in rural areas since 1999; and D). Sponsoring training for 600 teachers from 2009 to 2012.

\subsection{Health}

The company PT RAPP is committed to implementing health factors in the form of improving access and health services in rural areas. The program targets schools and assistance to health workers in the local village by providing nutritional supplements to mothers and babies in rural areas such as a). Since 1999-2012, as many as 132,716 residents have benefited from the APRIL Group's health program (PT.RAPP); and b). Since 2011-2012, the APRIL Group (PT.RAPP) has also run 25 health campaigns.

\subsection{Infrastructure}

The company PT RAPP is also committed to better facilities. Like building a number of infrastructure and improving facilities to support community activities by a). Building 178 places of worship and religious schools, 96 public schools and 17 sports facilities; b). Commit to building 30 health, water and sanitation facilities; and, c). Provides 98 electricity generators.

Based on the results of interviews and observations of the authors in addition to education, health and infrastructure, RAPP also conducts CSR activities such as: Contributing to the development of the environment and surrounding communities, Capturing quality and potential human resources, Reducing the risk of companies against corruption and losses, As a differentiator between companies and companies alternatives (competitors), Fostering a reasonable (good) relationship with the community outside the company, Potential costs (CSR will reduce the amount of taxes paid by the company), Establishing a reasonable (good) relationship with stakeholders (stakholder) outside such as the supplier. The conclusion of the Aid Proportion indicator is in the "Good" category.

\subsection{Transparency and Accountability}

PT. RAPP was established in 1993, in the village of Kerinci base, langgam sub-district, Pelalawan regency of Riau, which was built with an area of 650 hectares of 1750 hectares of land owned by PT. RAPP. While the head office and administrative affairs and cooperation are located on the street of General Sudirman, BNI floor 20-22, Jakarta. This location is very strategic because it is close to the source of raw materials so that the continuity of raw materials is guaranteed, water sources are easily obtained from the Kampar river which is 4.6 KM away from the factory, easy to cross East transportation and close to the port of Artificial.

Beginning in 1994 until March 1994 (for 3 months) began the start-up (test running) of the 
factory. In the middle of 1995 , the production commissioning period began for 5 months and after that began commercial production the following year .

PT. RAPP began full production in the third quarter of 1995. but has not yet reached the desired maximum target. Only in 1996 did the average production target of 2000 tons of pulp be achieved. All the benefits of pulp production produced by the Distributed Control System (DCS) . The system is the most advanced control system in the pilp industry of 850,000 tons / year, to support pulp production of 850,000 tons / year and as a raw material control plan, PT. RAPP has prepared a reserve area of $159,500 \mathrm{Ha}$ (according to Forestry Ministerial Decree No. 130 / KTS II / 1993 dated February 27, 1993). The 159,500 Ha area was used by $114,410 \mathrm{Ha}$ for the development of HTI (Industrial Plantation Forest) and the remaining $45,000 \mathrm{Ha}$ was used as plantations covering 11,770 $\mathrm{Ha}$, transmigration settlements $690 \mathrm{Ha}$, community gardens $16,410 \mathrm{Ha}$ and other uses covering 16,130 $\mathrm{Ha}$.

In terms of technology, most of the company's equipment is imported from Sond Pefibrator's factories in Finland and Sweden. These include wood cutting machines, Super Batch cutting systems, washing and pulp filters, oxygen delignification systems, bleach machines and second stage filters and power requirements obtained from steam turbine (PLTU). PT. RAPP is designed to produce the best pulp whose quality is counted as world class. This plant is equipped with the most recent systems and machinery such as super batch digester obtained from world-renowned suppliers and all control processes and monitored by a computer system from the local control room, besides the quality control is adjusted to ISO 900 , ISO 9002 and ISO 14000 procedures which is used as a sign to determine the quality of production. In 2000, PT. RAPP already has 2 production lines to expand to increase production targets. At present, a new production line is underway to meet the production target.

Based on the results of interviews and observations of the author, it was found that Good Corporate Governance, Verification and Transparency: PT. RAPP is committed to implementing best practices in terms of good corporate governance and in terms of transparency and accountability. PT. RAPP maintains a Stakeholder Advisory Committee (SAC), formed in 2014, to ensure transparency and application of the SFMP, including the appointment of an independent verification auditor; PT. RAPP establishes a transparent and responsive grievance mechanism with input from stakeholders that is easily accessed by stakeholders and will respond to complaints in a timely and transparent manner ; PT. RAPP will provide periodic reports on the progress of SFMP implementation to key stakeholders ; PT. RAPP is also working with government, industry associations and other stakeholders to support sustainable development, including the regulatory changes in the national and local scale to improve spatial planning, conservation incentives forests, supporting the role of the initiative "The Map" ( One Map ) by the Indonesian government and promote the use of degraded land. This is also done in the implementation of CSR activities. Therefore it can be concluded that the Transparency and Accountability category is in the "Good" category.

\subsection{Regional Cover}

Location of PT. Riau Andalan Pulp and Paper consists of two locations, the location of the factory in the village of Pangkalan Kerinci, Pelalawan Regency, Riau Province, $\pm 80 \mathrm{Km}$ east of Pekanbaru City and the distance of $\pm 5 \mathrm{Km}$ from the Kampar River. The head office is located at Jl. Jenderal Sudirman, BNI Building floor 20-22, Jakarta.

Based on the results of interviews and observations of the author, the scope of PT RAPP's CSR implementation is in 5 districts namely Pelalawan Regency, Siak Regency, Kuantan 
Singingi Regency, Meranti Regency, Kampar Regency. And the recipients of CSR activities are the Community, SMEs, community groups, and labor at the company. Besides that, PT. RAAP in implementing CSR divides the scope of priority areas, namely ring 1 , which is the area around the company consisting of 161 villages that routinely get positive effects from the implementation of CSR from PT.RAPP. . Therefore it can be concluded that the Regional Capping category is in the " Good Enough " category .

\section{Conclusion}

Based on the research results of the 4 indicators used are first, Leadership is in the category of "good". Second, the proportion is in the "good" category. Third, transparency \& accountability are in the "good" category. Fourth, the regional scope, is in the category of "good enough".

\section{Recomendation}

From the researcher's observations, there are a number of suggestions that are expected to be useful as research objects and for future researchers. Among others:

a) Provision of CSR should be as well organized as possible well and right on target. In other words, giving CSR truly is a tribute to the surrounding community, not just a company program. Because of that the company continues to look for approaches to providing CSR that are appropriate to the situation and conditions encountered.

b) RAPP companies, especially the Public Relations (Humas) section need to more intensively provide information about the "What" and "How" the CSR program actually is, so that the public knows the benefits for it from the program.

c) The need for long-term plans or increasing innovation by CDs in carrying out CSR programs .

d) This research still has limitations so it is recommended for further researchers to be able to conduct research in more depth. Both in terms of concepts, theories, and deepening of the data obtained from sources. The next researcher is expected to look more closely at the concept of Corporate Social Responsibility in order to obtain maximum data. In the future, it is also hoped that this research can be expanded to focus on research similar to studies in implementing CSR.

\section{References}

[1] Main, US (2018). Implementation of Corporate Social Responsibility of PT. Riau Andalan Pulp and Paper Against Communities in Pelalawan District. Strait Journal, 5 (2), 123- 133.

[2] Belilasari, B., Thamrin, T., \& Siregar, SH (2017). Analysis of the Implementation of the Corporate Social Responsibility (CSR) Program of PT. Perawang Sukses Perkasa Industri (PT. PSPI) in Kampar District, Kampar Regency, Riau Province in an Environmental Perspective. Environmental Dynamics, 4 (2), 147-157.

[3] Murni, S., Amin, MJ, \& Fitriyah, N. (2017). The Role of Corporate Social Responsibility (CSR) in Improving Village Community Development in Lung Anai Village, Loa Kulu District. Journal of 
Administrative Reform (JAR), 3 (1), 138-147.

[4] Ramadhan, R., \& Anwar, K. (2017). Corporate Social Responsibility PT. Riau Andalan Pulp and Paper In Teluk Meranti Subdistrict, Teluk Meranti Subdistrict Pelalawan Regency Year 2015-2016. Online Journal of Social and Political Sciences Faculty of Riau University Students, 5 (1), 1-14.

[5] Septa, F., \& Hendra, R. (2017). Implementation of CSR (Corporate Social Responsibility) Through the Partnership and Community Development Program By PT PLN (Persero) Tbk Riau Region and Riau Islands Pekanbaru Branch. Online Journal of Students (JOM) in Law, 3 (2), 1-15.

[6] Putra, IP, \& Wirman, W. (2017). Implementation of the Corporate Social Responsibility (CSR) Empowerment Program at PT. Pertamina Ru-ii Dumai. Online Journal of Social and Political Sciences Faculty of Riau University Students, 4 (2), 1-11.

[7] Ernie Tisnawati. 2009. Corporate Social Responsibility. Bandung: Refika Aditama 